\title{
Incidence of Negative Appendicectomy: Correlation Between Clinical, Peroperative and Histopathological Findings
}

\author{
Rahman $\mathrm{MZ}^{1}$, Islam $\mathrm{J}^{2}$, Hasanuzzaman $\mathrm{M}^{1}$, Habib $\mathrm{A}^{3}$, Bhattacharjee $\mathrm{A}^{1}$ \\ ${ }^{I}$ Surgical Oncology Department, National Institute of Cancer Research \& Hospital (NICRH), \\ ${ }^{2}$ Cancer Epidemiology Department, National Institute of Cancer Research \& Hospital (NICRH), \\ ${ }^{3}$ Upazila Health Complex, Dhamrai, Dhaka
}

\begin{abstract}
Appendicitis is one of the most difficult diagnostic problems to confront the emergency physician and it is the most common intra-abdominal condition requiring emergency surgery. The term "Negative appendicectomy" used for operation done for suspected appendicitis, in which the appendix is found to be normal on histological evaluation. The study aimed to find out the incidence of negative appendicectomy evaluating the correlation between clinical, per-operative and histopathological findings. It was a prospective study of 100 cases clinically diagnosed as acute appendicitis selected over a period of one year (July 2006 to June 2007) from different surgical ward of Mymensingh Medical College Hospital. The study revealed a negative appendicectomy rate of $12 \%$. Moreover, in all cases of acute appendicitis, there was a well established bias towards male patients and young male patients constituted the majority of the cases. But the rate of negative appendicectomy found to be higher in female patients, which is $15.9 \%$ as compared to only $8.92 \%$ male patients. In addition, among female patients differential diagnostic difficulties encountered in females of reproductive age group. More emphasis on technology at the expense of clinical evaluation is certainly responsible for the diminish in accuracy of diagnosis. The diagnosis of acute appendicitis remains essentially clinical, requiring a mixture of observation, clinical acumen and accurate use of diagnostic tools. A correct diagnosis is certainly important than a rapid diagnosis.
\end{abstract}

e-mail:zrdr27@gmail.com

Key words: Negative appendicectomy, Clinical, Peroperative and Histopathological correlation

\section{Introduction}

Acute appendicitis is the most common intra-abdominal condition requiring emergency surgery with a lifetime risk of six percent. ${ }^{1}$ Despite more than 100 years of experience and extraordinary advancement in modern imaging and laboratory investigations, the accurate diagnosis of acute appendicitis still evades the surgeons, and subsequent complication must be weighted against removal of a normal appendix in patients with other causes of abdominal pain,a "negative" appendicectomy, which has a rate as high as $20 \%$. $^{2}$ The term 'negative appendicectomy' is used for an operation done for suspected appendicitis, in which the appendix is found to be normal on histological evaluation. ${ }^{3}$

Acute appendicitis is also a common surgical condition in our country and among the most commonly performed operations appendicectomy is one. Surgeons infrequently encounter and remove the normal appendix or find other pathology on exploration.

The high rates of negative appendicectomy are because of diagnostic inaccuracy of the clinician and also of available diagnostic tools. More emphasis on technology at the expense of clinical evaluation is certainly responsible for the diminish in accuracy of diagnosis as well as quality of care. ${ }^{4} \mathrm{~A}$ correct diagnosis is more important than a rapid diagnosis and can safely be managed by active observation with an improved diagnostic work up under observation, that may lower the negative appendicectomy rate. In case of young females gynaecological problems frequently mimic appendicitis and in both sexes may be falsely diagnosed as acute appendicitis having other pathology. Occasionally peroperative normal looking appendix shows infiltration with inflammatory 
cells on histopathology specially found in catarrhal infection, but histologically normal appendix may not exclude acute appendicitis, as in the case of Neuroimmune appendicitis ${ }^{5}$ which may be a distinct pathological entity. Thus diagnosis of acute appendicitis remains essentially clinical, requiring a mixture of observation, clinical acumen and accurate use of diagnostic methods.

From our long clinical experience it can be said that routine histopathological examination of removed vermiform appendix is not a regular practice in our country, although it is expected to have histopathological examination of all the appendicectiomy specimens. One of the main objectives of the current study was to upgrade the clinical efficacy in terms of diagnosis of acute appendicitis and careful observation of the patients in hospital in order to reduce the incidence of negative appendicectomy. In the current study an attempt has been made to correlate between clinical and peroperative diagnosis with histopathological diagnosis.

\section{Materials and Methods}

This observational study was carried out in different surgical units of Mymensingh Medical College Hospital (MMCH) from July 2006 to June 2007. This study included 100 patients through convenient and purposive sampling, who were admitted with clinical diagnosis of acute appendicitis and underwent emergency appendicectomy. Operations were mainly performed by Assistant Professors and Assistant Registrars of the concerned surgical units. Specimens were sent to pathology department of MMC for histopathological diagnosis. The study was approved by the Ethical Review Committee of MMCH and informed consent was taken from each patient before their enrollment in the study. Data were collected in a pretested semi-structured questionnaire. Date were collected in a pre-tested semi-structured questionnaire. Date were checked, coded manually and then entered into computer. Data analysis was done by SPSS for Windows (IBM SPSS statistics for Windows, version 22.0) software. To see the association between two categorical variables Chi-squared test and Fisher's Exact test were done. Statistical significance was taken at 0.05 probability level.

\section{Results}

The age of the patients ranged from 5 to 60 years with a median of 23 years. The overall incidence of positive and negative findings of 100 cases based on clinical and laparotomy findings that is confirmed by histopathology report in relation to age group and sex in displayed in Table I. Out to 56 male and 44 female patients 51 and 37 patients suffered attack of appendicitis respectively (Table I).

Table I: Positive and Negative findings in relation to age and sex $(n=100)$

\begin{tabular}{ccccc}
\hline Variables & $\begin{array}{c}\text { No. of Pa- } \\
\text { tients }\end{array}$ & $\begin{array}{c}\text { Appendici- } \\
\text { tis }\end{array}$ & $\begin{array}{c}\text { Nega- } \\
\text { tive } \\
\text { Find- } \\
\text { ings }\end{array}$ & $\begin{array}{c}\boldsymbol{p} \text { - } \\
\text { value }\end{array}$ \\
\hline Age(years) & & & & \\
\hline $0-10$ & 05 & 04 & 01 & \\
$11-20$ & 44 & 39 & 05 & \\
$21-30$ & 32 & 29 & 03 & \\
$31-40$ & 09 & 07 & 02 & \\
$41-50$ & 07 & 06 & 01 & \\
$51-60$ & 03 & 03 & 00 & \\
sex & & & & \\
Male & 56 & 51 & 05 & 0.286 \\
Female & 44 & 37 & 07 & \\
\hline
\end{tabular}

Forty eight cases presented with classical symptoms of acute appendicitis, 29 complaints of pain in the right lower quadrant of abdomen. Other patients presented with atypical symptoms like vague pain in abdomen, pain in suprapubic region and some patients complaints of associated diarrhea or difficulties on urination (Table II).

Table II: Mode of presentation $(n=100)$

\begin{tabular}{|c|c|}
\hline Presenting Symptoms & $\begin{array}{c}\text { No. of the } \\
\text { patients }\end{array}$ \\
\hline $\begin{array}{l}\text { Central abdominal pain that shifted to right iliac } \\
\text { fossa, anorexia, nausea, vomiting. }\end{array}$ & 48 \\
\hline $\begin{array}{l}\text { Pain in the right lower quadrant of abdomen, } \\
\text { vomiting, mild fever. }\end{array}$ & 29 \\
\hline $\begin{array}{l}\text { Vague pain in the abdomen, vomiting and diarro- } \\
\text { hea. }\end{array}$ & 08 \\
\hline $\begin{array}{l}\text { Pain in the suprapubic region, vomiting, mild fe- } \\
\text { ver. }\end{array}$ & 06 \\
\hline Colicky pain in the lower abdomen and dysuria. & 05 \\
\hline $\begin{array}{l}\text { Pain in the right lower quadrant of abdomen, } \\
\text { vomiting, amenorrhea. }\end{array}$ & 01 \\
\hline $\begin{array}{l}\text { Sudden severe pain in the right lower quadrant of } \\
\text { abdomen, vomiting, high rise of temperature with } \\
\text { irregular menstrual history. }\end{array}$ & 03 \\
\hline
\end{tabular}

Seventeen patients was suffered from previous attacks of similar pain in right lower abdomen and improved spontaneously or on conservative managements. The final diagnosis was obtained form peroperative findings and was confirmed by histopathology interpretation. With adequate preoperative preparation, approach was made under 
general anesthesia and in majority of the cases Grid-iron incision.

Table III: Laparotomy findings of Vermiform Appendix

\begin{tabular}{lc}
\hline Laparotomy findings & $\begin{array}{l}\text { No. of the } \\
\text { patients }\end{array}$ \\
\hline Per-operative naked eye apperance & \\
\hline Acutely Inflamed appendix & 48 \\
Acute suppurative appendicitis & 14 \\
Acute suppuration with perfora & 02 \\
tion of appendix & 09 \\
Gangrenous appendix & 03 \\
Fibrosed appendix & 24 \\
Apparently normal appendix & \\
Findings inside the lumen & 34 \\
Faecolith & 06 \\
Fibrinous exudates & 25 \\
Purulent exudates & 11 \\
Faecal material & 01 \\
Round Worm (Partial) & 02 \\
Pin Worm & 21 \\
Empty & \\
\hline
\end{tabular}

On laparotomy acutely Inflammed appendix were found in 48 cases and acute suppurative appendicitis were noted in 14 casees. Apparently normal looking appendix was found in 24 specimens ( $\mathrm{Ta}-$ ble III).After the operation lumen of appendix was examined after splitting. Faecolith was encountered in 32 specimens (Table III). Specimens of resected appendix were send for histopathological examination which revealed confirmatory features of acute appendicitis by invasion of muscularis propria with neutrophils in 52 specimens; features of suppuration was found in 19 specimens and gangrenous features in 14 specimens. Twelve specimens showed normal appendix (among them five were male and seven were female) (Table IV).

In present series $88 \%$ of the surgically removed appendices were histopathologically confirmed as appendicitis. Out of 24 apparently normal looking appendix, 50\% was diagnosed as appendicitis on histopathological examination. This present study shows a histologically confirmed negative appendicectomy rate of $12 \%$ (Table IV).
Table IV: Result of Histopathology and diagnostic accuracy $(n=100)$

\begin{tabular}{lc}
\hline \multicolumn{1}{c}{ Parameters } & $\begin{array}{c}\text { No. of the } \\
\text { patients }\end{array}$ \\
\hline Histopathology & 52 \\
Uncomplicated acute appendicitis & 19 \\
Acute suppurative appendicitis & 14 \\
Acute gangrenous appendicitis & 02 \\
Resolving appendicitis & 01 \\
Obliterative appendicitis & 12 \\
Normal appendix & \\
Diagnosis & 88 \\
Correct diagnosis & 12 \\
Incorrect diagnosis & \\
\hline
\end{tabular}

Table V: Correlation of clinical features and leukocyte count with types of appendicitis $(n=100)$

\begin{tabular}{lccc}
\hline Parameters & $\begin{array}{c}\text { Appendici- } \\
\text { tis }\end{array}$ & $\begin{array}{c}\text { Negative } \\
\text { for } \\
\text { appendici- } \\
\text { tis }\end{array}$ & $\begin{array}{c}p \text { - } \\
\text { value }\end{array}$ \\
\hline $\begin{array}{l}\text { Clinical presentation } \\
\text { Classical }\end{array}$ & 73 & 4 & $<0.001$ \\
Other & 15 & 8 & \\
$\begin{array}{l}\text { Leukocyte count } \\
\text { Within }\end{array}$ & & & \\
$\begin{array}{l}\text { normal range } \\
\left(<10,000 / \mathrm{mm}^{3}\right)\end{array}$ & 05 & 09 & \\
$\begin{array}{l}\text { Increased } \\
\left(>10,000 / \mathrm{mm}^{3}\right)\end{array}$ & 83 & 3 & $<0.05^{*}$ \\
\hline *Fisher's Exact test & & & \\
\hline
\end{tabular}

Correlation of clinical features and leukocyte count with types of appendicitis is given in the table $\mathrm{V}$.

Table VI: Correlation of clinical features and histology findings $(n=100)$

\begin{tabular}{lllll}
\hline $\begin{array}{l}\text { Clinical } \\
\text { features }\end{array}$ & UAA & CAA & NA & $\begin{array}{c}p- \\
\text { value }\end{array}$ \\
\hline Pain & 54 & 34 & 12 & \\
$\begin{array}{l}\text { Nausea } \\
\text { \& Vom- }\end{array}$ & 38 & 21 & 5 & 0.644 \\
iting & & & & \\
\hline
\end{tabular}

UAA Uncomplicated acute appendicits; CAA Complicated acute appendicits; NA Normal appendix

Classical features of appendicitis were significantly less in negative appendicitis cases whereas significantly more subjects with appendicitis showed leukocytosis (Table V). Correlation of clinical features and histology finding is presented in the table VI. However, no statistically significant difference was observed regarding this. 


\section{Discussion}

In the present series, we have studies a total of 100 cases of clinically diagnosed acute appendicitis admitted in different surgery units of $\mathrm{MMCH}$. Acute appendicitis is a diseases of the young, ${ }^{1,6-9}$ and this statement is reinforced by the current study finding. However, no age is immune and the age range in this series was 05 to 60 years which conforms to findings of other studies. In addition, in all age group, there was a well-established bias towards male patients and young male patients constitute the majority of the cases. These observations are similar to those observed in other studies. ${ }^{10,6-8,11}$

This present series shows a negative appendicectomy rate of $12 \%$ (i.e. "normal appendices at histopathology). This figure is in agreement with other studies which have reported a normal appendicectomy rate $10 \%$ and $30 \% .^{11-15}$

The appendices from $15.9 \%$ of females showed normal histology as compared to only $8.92 \%$ males also shown in this series. The predominance of females in the normal group undergone negative appendicectomy has been observed by other authors also. ${ }^{16,17}$ Moreover, majority of negative appendicectomies were performed in women of child bearing age. This reflects the differential diagnostic difficulty in fertile females.

Histopathology result of this series has shown $52 \%$ patients suffered uncomplicated acute appendicitis while suppurative and gangrenous changes were seen in $19 \%$ and $14 \%$ cases respectively. The rate of gangrenous appendicitis as reported in a study from New Zealand ${ }^{18}$ was $5.1 \%$. Probably this reflects the greater time delay in presenting to the hospital from our part of the world. This might be on account of ignorance and reluctance on the part of the patient to seek medical treatment. Obstruction of appendiceal lumen by faecolith or lymphoid hyperplasia is said to be of importance in the pathogenesis of acute appendicitis. ${ }^{19-22} \mathrm{~A}$ hypothesis was also given by Condon ${ }^{23}$ in 1977 concerning the relationship between the incidence of acute appendicitis and the amount of appendiceal lymphoid tissue. In this current study naked eye examination of resected appendix after splitting open revealed faecolith in 34\% cases. This is consistent with the report of Burkitt ${ }^{24}$ who found faecolith in $40 \%$ cases. In this study laparotomy finding of apparently normal looking appendix was $24 \%$ and histopathology reported $52 \%$ cases as uncomplicated acute appendicitis. Probably these patients had acute colicky to persistent abdominal pain due to obstruction of the lumen of the vermiform appendix, and thus clinically presented as acute appendicitis, but did not have matching histopathologic picture. Moreover, lymphoid hyperplasia could have been one of the major causes of high incidence of appendicitis in children and young adults. ${ }^{9,21}$ Normal appearing appendix might show increased cytokines in histologically normal appendix does not always mean a normal appendix. This has been reported that some histologically normal appendices in patients with acute pain in the right iliac fossa contain abnormal concentrations of neuropeptides, which may explain the relief of pain after removal of a histologically normal appendix..$^{5,26}$

Correlation of clinical features and leukocyte count with types of appendicitis was done. It was found that classical features of appendicitis were significantly less in negative appendicitis cases and significantly more subjects with appendicitis showed leukocytosis. Correlation of clinical features and histology findings was also observed in the present study. These findings are consistent with other study findings. $8,11,15$

\section{References}

1. Singhal R, Angmo N, Somaiah N, Majumder H, Chaturvedi KU. A retrospective review of the histopathology and clinicopathologic correlates of appendices removed from patients of acute appendicitis. Minerva Chir 2007;62:11-18.

2. Benjamin IS, Patel AG. Managing acute appendicitis- Laparoscopic surgery is particularly useful in woman. BMJ 2002;7(325):505-06.

3. Humes D. and Simpson J. Acute appendicitis. BMJ 2006;333(7567):530-34.

4. Jones PF. Suspected acute appendicitis: Trends in management over 30 years. Br J Surg 2001;88:1570-77.

5. DiSebastiano P, Fink T, diMola FF, Weihe E, Buchler MW. Neuroimmune appendicitis. Lancet 1999;354:461-66.

6. Azad M.A.S. Correlation between clinical diagnosis of acute appendicitis and operative findings- a study of 100 cases in a teaching hospital [Dissertation]. Department of surgery, BSMMU, Dhaka. 2003. 
7. Chee CP, Somasudaram K. Acute appendicitis, the significance of positive rectal examination and the position of Vermiform appendix. Singapore Med J. 1982; 23:268.

8. Kabir E. Acute appendicitis. Correlation between clinical, peroperative and histopathological diagnosis. A prospective study of 90 cases.[Dissertation]. IPGM\&R, Dhaka; BCPS 1996.

9. Lee JAA. The influence of sex and age on appendicitis in children and young adults. Gut $1962 ; 3: 80-84$.

10. Chang A.R. An analysis of the pathology of 3003 appendices. Aust NZ J Surg; 1981;51:16978.

11. Mahbub RE, Khan B.R., Biswas K.A. A comparative study of clinical and histodiagnosis of acute appendicitis[Dissertation]. Bang. Alcd. J 1991;20-224

12. Silberman VA. Appendicectomy in a large Metropolitan hospital: retrospective analysis of 1013 cases. A J Surg 1981;142:615-18.

13. Islam MS. Clinicopathological study of acute appendicitis in a teaching hospital: astudy of 100 cases [Dissertation]. Department of surgery, MMCH. 2001.

14. Chan KW, Fu KH, Liung J. The pathology of the appendix in Hong Kong. $\mathrm{Br} \mathrm{J}$ Chin Pract 1988;42:241-44.

15. Lewis FR, Holcroft JW, Boyey J, Dunphy E. Appendicitis: a critical review of diagnosis and treatment in 1000 cases. Arch surg 1975;110: 677-84.
16. Adekunle O.O., Funmilayo J.A. Acute appendicitis in Nigeria. JR Coll Surg. Edinb 1986;31:102-05.

17. Ojo OS, Udeh SC, Odesanmi WO. Review of the histopathologic findings in appendices removed for acute appendicitis in Nigerians. JR Coll Surg Edinb 1991; 36: 245-48.

18. Mbembati NAA, Lema L, Mwakyoma, Ussiri EV. Afr J Med 1991; 42: 68-70.

19. Bowers WF. Appendicitis with special reference to pathogenesis, bacteriology and healing. Arch Surg 1939;39:362-422.

20. Morson BC, Dawson IMP. Gastrointestinal pathology. Oxford: Blackwell; 1972.

21. Hwang JMS, Krumbhaar EB. The amount of lymphoid tissue of the human appendix and its weight at different age periods. AM J Med Sci 1940;199:75.

22. Shaw RE. Appendix calculi and acute appendicitis. Br J Surg 1965; 52:451-59.

23. Condon ER. Appendicitis. In: Sabiston D.C. Jreditor. Davis Christopher Textbook of Surgery, $11^{\text {th }}$ ed. Philadelphia: WB Saunders; 1977; P.1062-78.

24. Burkitt D.P. The aetiology of appendicitis. Br J Surg. 1971;58:695-99.

25. Bijnen CL, Vanden Broek WT, Bijnen AB, Ruiter De P, Gouma DJ. Implication of removing a normal Appendix. Dig Surg 2003;20:215221.

26. Wang Y, Reen DJ, Puri P. Is a histologically normal appendix following emergency appendicectomy always normal? Lancet 1996;347:1076-79. 